\title{
Effects of Fuel Additive on Performance and Emissions Characteristics of Diesel Engine Fuelled by Biodiesel Derived from Palm Oil
}

\author{
Amir Khalid ${ }^{1, a}$, Azmi Abas $^{2, b}$ \\ ${ }^{1}$ Automotive Research Group (ARG), Centre for Energy and Industrial Environment Studies \\ (CEIES), Universiti Tun Hussein Onn Malaysia, Parit Raja, Batu Pahat, 86400 Johor, Malaysia. \\ ${ }^{2}$ D2O Resources Sdn. Bhd, C-01-15, Jalan Sri Kenari 12, Taman Sri Kenari, 43000 Kajang, \\ Selangor, Malaysia. \\ aamirk@uthm.edu.my, bmieonkyo@gmail.com
}

\section{Key Words: Booster, Diesel Engine, Biodiesel, Emissions, Palm Oil, Alternative Fuel}

\begin{abstract}
Biodiesel is the alternate fuel which is derived from renewable sources either is vegetable oils or animal fats. Biodiesel is non-toxic, have higher biodegradability, free of sulphur, no aromatics and its oxygen content of about $10-11 \%$ which is usually not contained in diesel fuel. These characteristics thus predominantly influences to the emissions of carbon monoxide (CO) and hydrocarbons (HC) in the exhaust gas. Purpose of this study is to investigate the effects of fuel additive, oil palm blended fuel, engine speed and test load conditions on the exhaust emissions and engine performance. The engine speed was varied from 1500 to $3000 \mathrm{rpm}$, load test condition varied by dynapack chassis dynamometer in 0,50 and 100\% and blends of 5(B5), 10(B10) and $15 \mathrm{vol} \%(\mathrm{~B} 15)$ palm oil with the diesel fuel. Increased of blends ratio with same mixing booster quantity can improve the engine performance, combustion process and give less $\mathrm{CO}$ emission. However, this condition tends to produce high NOx production due to higher oxygenated fuel in biodiesel content.
\end{abstract}

\section{Introduction}

Biodiesel which can offer the aspects as above is getting the higher attention from human being and the properties, performance and emissions of biodiesel have been further investigated. However, most biodiesel fuels have faced the problem where the fuels are not operating efficiently due to the variant in fuel properties. In diesel engine, the relation between mixture formation during the ignition delay period and burning process in diesel combustion that strongly affects the exhaust emissions [1-5]. Crude palm oil (CPO) has considerably biodegradable, higher viscosity and density compared to diesel fuel. The biodiesel also is renewable, non-toxic, less sculpture and aromatic contents. It can reduce the $\mathrm{HC}, \mathrm{CO}$, and $\mathrm{PM}$ which directly causes less greenhouse gas emissions. However the viscosity of fuels has important effects on the fuel droplet formation, atomization, vaporization and fuel-air-mixing process, which influencing the exhaust emissions and performance parameter of the engine [6-9]. In addition, higher viscosity will increase the fuel quantity, injection timing and spray pattern which influence the initial premixing and the combustion process. Hence, many researches show emissions concentrations $\left(\mathrm{CO}, \mathrm{CO}_{2}, \mathrm{PM}, \mathrm{HC}, \mathrm{O}_{2}\right.$ and $\left.\mathrm{NOx}\right)$ vary depending on the properties of biodiesel [10-13]. This research investigate the effects of booster racing formula, oil palm blended fuel, engine speed and test load conditions on the exhaust emissions and engine performance. It is expected that this work will provide the knowledge of the effects blending of booster properties and oxygenate fuel due to the variant in biodiesel blending ratio on combustion characteristics, emissions and performance.

Experimental Setup- Under with booster racing formula condition, the biodiesel fuel was blended with blending ratio of 50 liter biodiesel for $1.0 \mathrm{ml}$ of booster additive for all conditions. The biodiesel used was Crude Palm Oil biodiesel which blended form automotive lab and the particular of the tested fuel are detailed in Table 1.The fuel tested were grade II diesel and blends of 5(B5), 10(B10) and $15 \mathrm{vol} \%(\mathrm{~B} 15)$ palm oil with the diesel fuel. The grade II diesel designated as ordinary diesel (OD). The kinematic viscosity of palm oil blend was measured by Viscolite 700 model 
VL700-T15. The density properties measured by Metter Toledo Diamond Scale modeled JB703$\mathrm{C} / \mathrm{AF}$. The water content in biodiesel sample is measured by Volumetric KF Tirator model v20. The flash point measured by Pensky-Martens PMA 4. The engine fuel consumption measured by Ono Sokki mass flow meter modeled FM2500.

Table 1: Properties of biodiesel fuels

\begin{tabular}{|c|c|c|c|c|c|}
\hline \multirow{2}{*}{ Fuel type } & \multicolumn{5}{|c|}{ Properties } \\
\cline { 2 - 6 } & $\begin{array}{c}\text { Density } \\
(\mathrm{g} / \mathrm{cm} 3)\end{array}$ & $\begin{array}{c}\text { Kinematic } \\
\text { viscosity } \\
(\mathrm{Cp})\end{array}$ & $\begin{array}{c}\text { Flash point } \\
\left({ }^{\circ} \mathrm{C}\right)\end{array}$ & $\begin{array}{c}\text { Water } \\
\text { content } \\
(\mathrm{ppm})\end{array}$ & $\begin{array}{c}\text { Acid value } \\
(\mathrm{mg} \text { KOH/g) }\end{array}$ \\
\hline OD & 0.83374 & 3 & 80 & 79.6 & 0.423 \\
\hline B5 & 0.84453 & 4 & 85 & 140 & 0.6732 \\
\hline B10 & 0.85229 & 4.1 & 85.5 & 146.1 & 0.7293 \\
\hline B15 & 0.85428 & 4.3 & 87 & 191.9 & 0.9537 \\
\hline
\end{tabular}

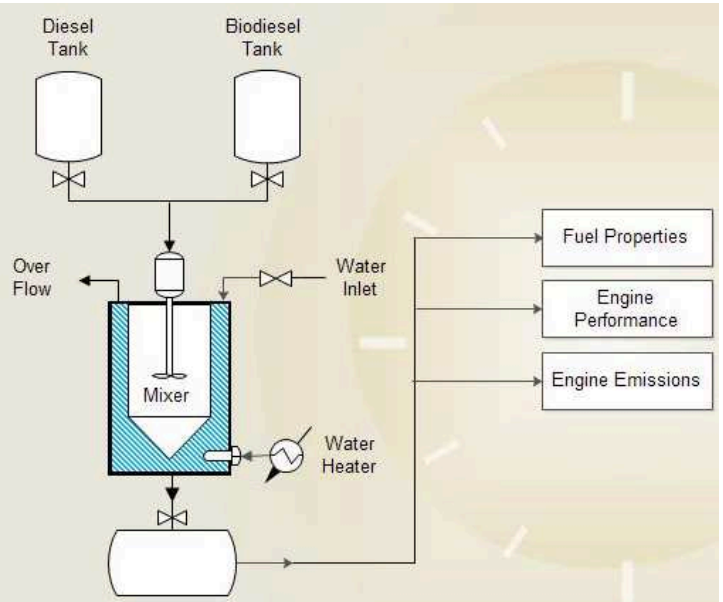

Figure 1: Blending process of producing biodiesel

Schematic view of blending process is shown in Figure 1. The crude palm oil was blended with OD in various concentrations for preparing a biodiesel blend. During blending process, the laboratory scale blending machine was operated at $60^{\circ} \mathrm{C}$ and the mixture was stirred at $70^{\circ} \mathrm{C}$ for 1 hour. The rotating blade speed was adjusted to maintain the same speed at $270 \mathrm{rpm}$. Table 2: Engine specifications

\begin{tabular}{|l|l|}
\hline Engine & Mitsubishi \\
\hline ModelCode & S-L049GV-NTD \\
\hline Engine Model & 4 D56 (turbocharger) \\
\hline Engine type & Serial4 cylinder OHC turbo \\
\hline Fueltype & Diesel \\
\hline Fuel system & Distribution type jet pump \\
\hline Bore/stroke $(\mathrm{mm})$ & $91.1 / 95$ \\
\hline Maximum power & $85 \mathrm{ps}(62.52 \mathrm{kw}) / 4200 \mathrm{rpm}$ \\
\hline Maximum Torque & $20.0 \mathrm{~kg}-\mathrm{m}(196 \mathrm{~N}-\mathrm{m}) / 2000 \mathrm{rpm}$ \\
\hline Displacement & $2476 \mathrm{cc}$ \\
\hline Compression Ratio & 21.0 \\
\hline Supercharger & TURBO \\
\hline Vehicle Weight & $1590 \mathrm{~kg}$ \\
\hline
\end{tabular}

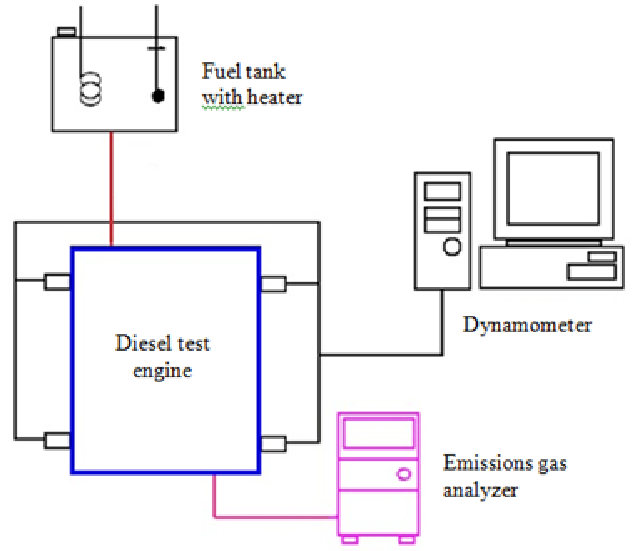

Figure 2: Schematic of Dynopack Chasis setup

A schematic view of the chassis dynamometer testing and summarizes the engine specification including the operating parameter and fuel injection system are shown in Fig. 2 and Table 2, respectively. A series of measurements were conducted on a test commercial vehicle (Mitsubishi Pajero) intended for automotive application. The experimental program was carried out using the commercial vehicle of four-cylinder four stroke-cycle DI diesel engine (Mitsubishi S-L049GVNTD). The engine is equipped with turbocharged with maximum power of $62.52 \mathrm{~kW}$ (4200 rpm) and compression ratio of 21:1.The engine fuel consumption was measured using a precision ONOSOKKI volumetric fuel flow meter, and are pegged between the preheat fuel tank and the fuel pump. The engine was loaded by Dynapack Chassis Dynamometer Machine model 4022. The engine speed was adjusted at variant of 1500, 2000, 2500 and $3000 \mathrm{rpm}$. The dynamometer loads were at 0,50 and $100 \%$ load. Measurements vehicle performance data comprised brake power( $(\mathrm{kW})$, flywheel torque $(\mathrm{Nm})$, fuel consumption rate $(\mathrm{kg} / \mathrm{hr})$ together with the exhaust emissions like hydrocarbon $(\mathrm{HC})$, oxygen $\left(\mathrm{O}_{2}\right)$, carbon dioxide $\left(\mathrm{CO}_{2}\right)$, carbon monoxide $(\mathrm{CO})$, nitrogen oxides (NOx) and smoke opacity by using autocheck 5 channel gas emission analyzer and danger MSI. For this research, B5, B10, B15 are used for running under similar engine in a manner similar operation conditions. To compare the difference, the measurement process was repeated for 
3 cycles per each condition. Further analysis and presentation of data is based on the average of measurement.

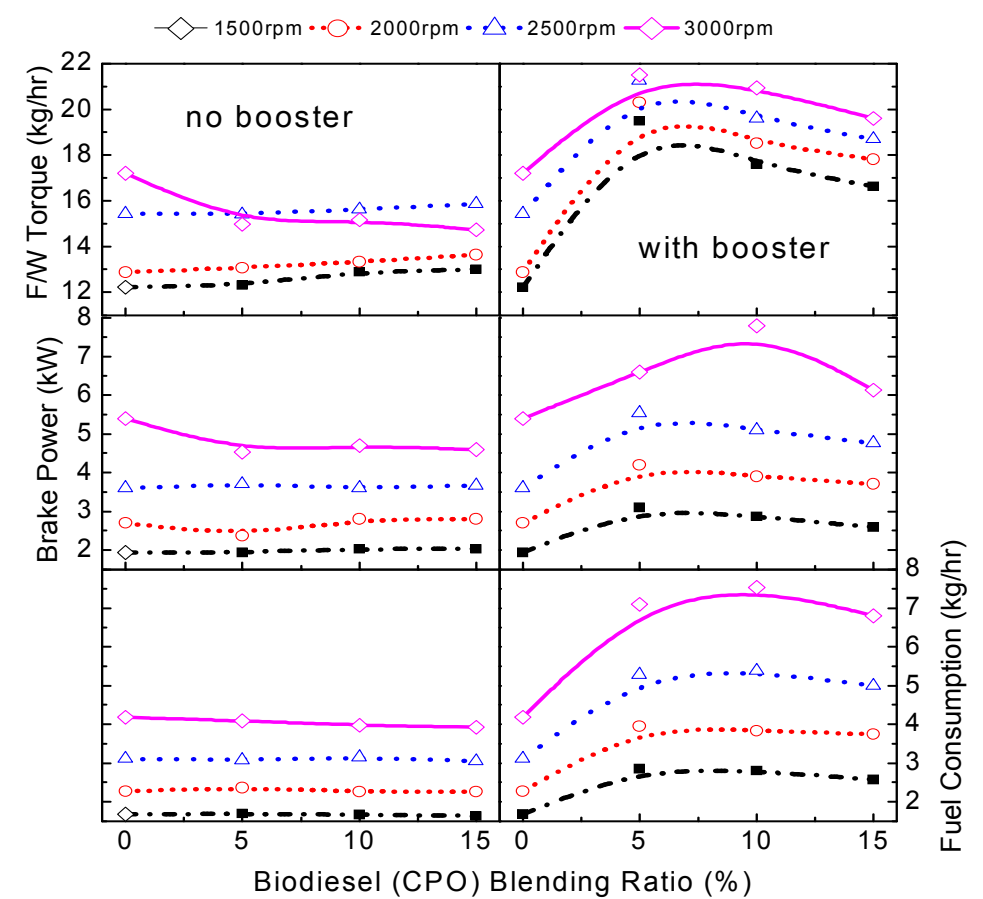

Figure 3 Effects of $\mathrm{CPO}$ blending on engine performance ( $0 \%$ load conditions)

\section{Results and Discussion}

The effect of booster racing formula and biodiesel blending ratio on the performance and emission was investigated. Figure 3 clearly shows the performance versus blending ratio in load $0 \%$ under different engine speed. The brake power, flywheel torque and torque were obtained from chassis dynamometer. As seen in Fig. 3, increased of blends ratio with same mixing booster quantity can improve the brake power and torque but small change of fuel consumption, as compared to the without booster condition. It may due to complete combustion of oxygenated fuel. The flywheel torque and torque in high engine speed $3000 \mathrm{rpm}$ increase with the increasing of blending ratio due to the improving of the ignition process and combustion process in the cylinder.

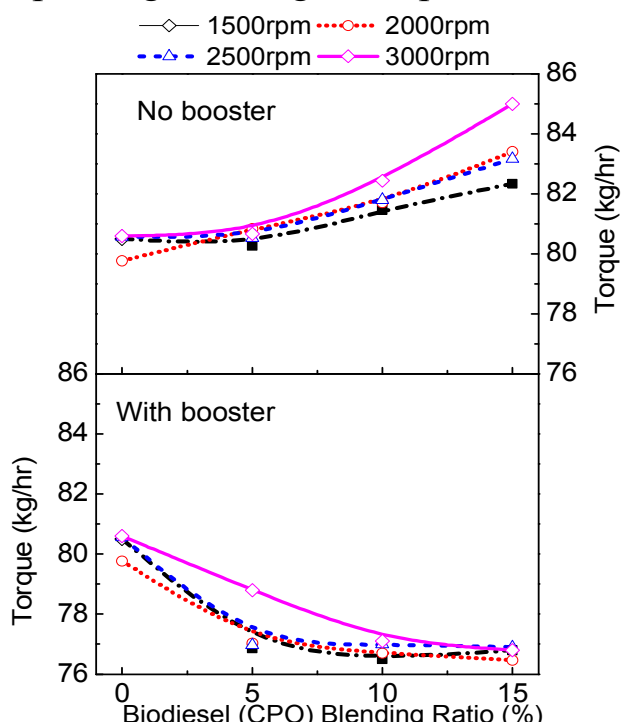

Figure 4 : Effects of CPO blending ratio on flywheel torque and torque (50\%load conditions)

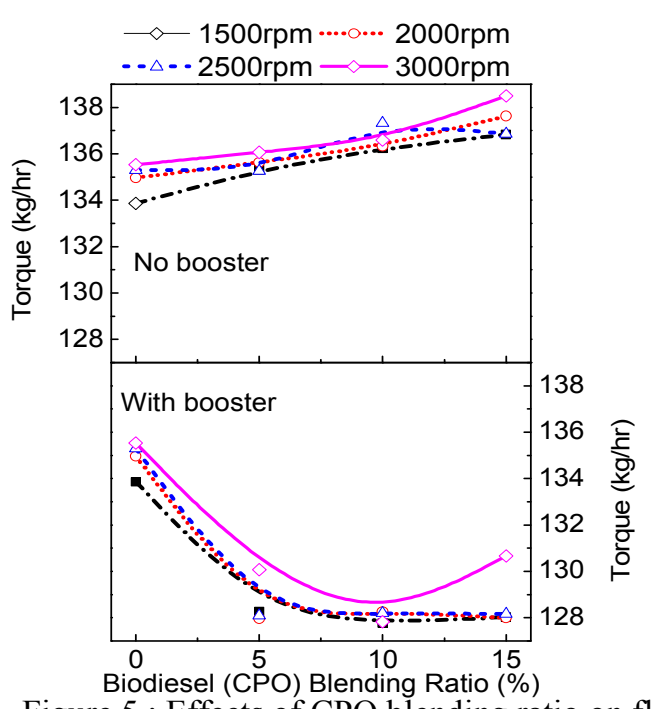

Figure 5 : Effects of CPO blending ratio on flywheel torque and torque (100\% load condition) conditions.

Next, Figure 4 and Figure 5 compare the engine torque with variant in load condition. As seen in Figure 4 and Figure 5, under with booster condition, the distribution of torque decreases much more slowly by the blending ratio in high load condition and increases as the blending ratio increases. It may attributed to high load propose more fuel quantity and not fully utilized high oxygen content 
in the fuel, thus decrease the torque of the engine. Figure 6 compares the effect of booster additive and higher fuel blends on combustion characteristics. The increase of blending ratio together with booster is found that increase the Nitrogen Oxide (NOx) emission. This behavior could be associated with the influences of booster additive and higher oxygen content in high blending ratio thus influences on combustion process. Under with booster condition, higher blends of biodiesel have more oxygen content, which result more complete combustion and directly decrease carbonmonoxide $(\mathrm{CO})$ emission.
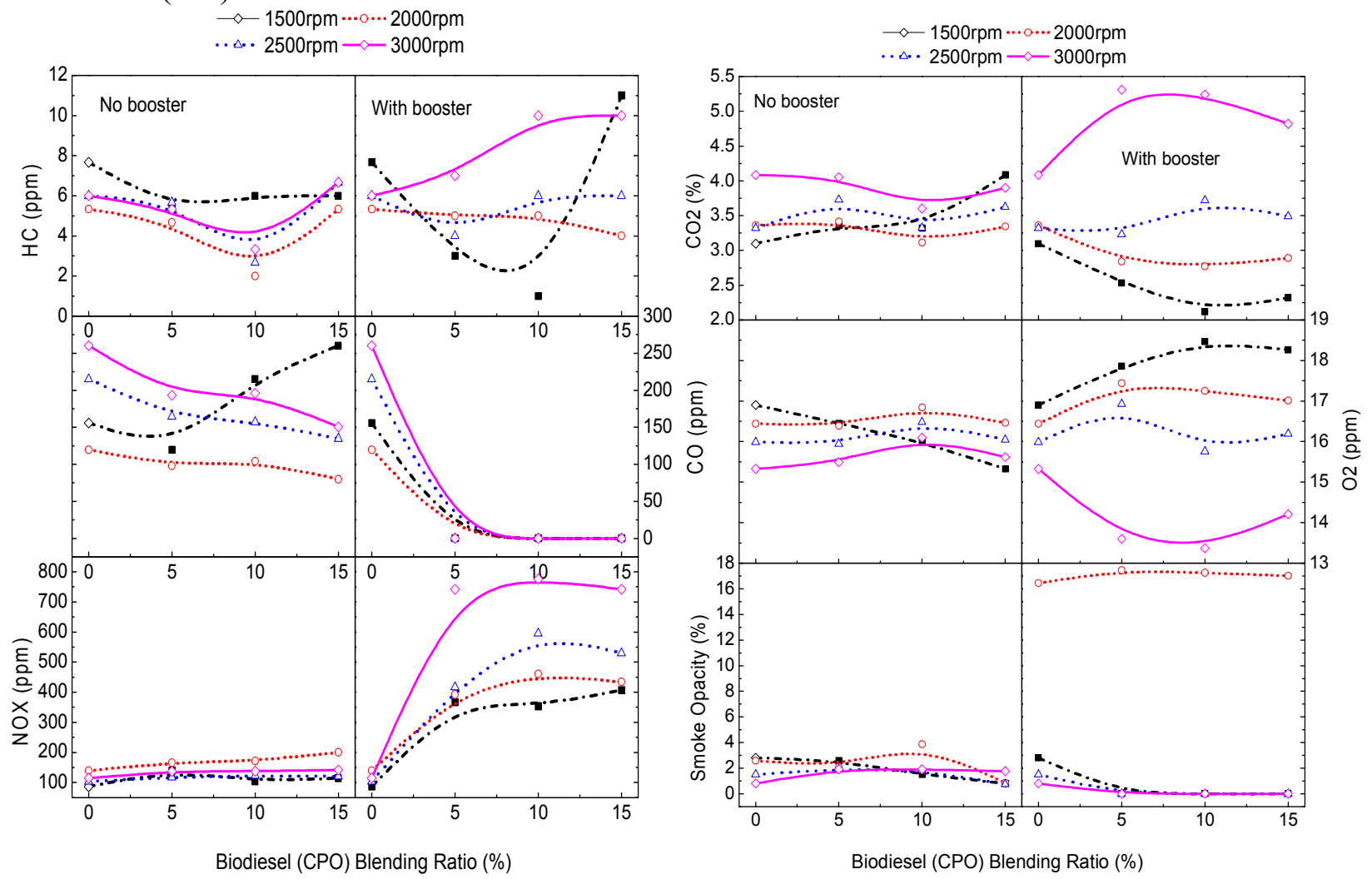

Figure 6 : Effects of CPO blending on emissions ( $0 \%$ load condition)

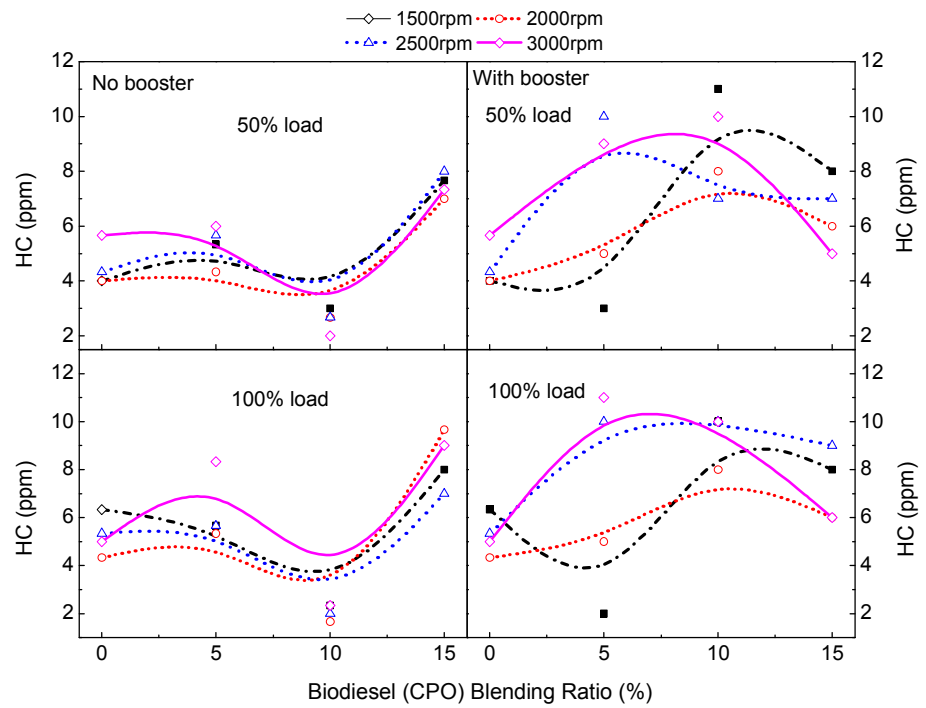

Figure 7: Effects of CPO blending and load conditions on HC emissions conditions.

Figure 7 compares the effect of booster additive and load condition on Hydrocarbon (HC) emission. Increase blending ratio (B10) under with booster condition will have the increase $\mathrm{HC}$ emission either in 50 or 100 loads under all engine speed. It also shows the highest emission during the B15 under the same condition. It seems that the increasing of blending ratio with booster additive will improve the fuel ignitibility and burning process. This circumstances result in lower combustion pressure and temperature during late of combustion. Thus, the higher $\mathrm{HC}$ emission is strongly related to lower combustion temperature. 


\section{Conclusion}

Engine performance and emissions results of the additional of booster racing formula and biodiesel (BDF) derived from different CPO (B5, B10, B15) were compared with the results obtained with and without booster. The results of the study may be summarized as follows:

1. Increased of blends ratio with same mixing booster quantity can improve the brake power and torque but small change of fuel consumption, as compared to the without booster condition.

2. The blends biodiesel with booster promote the reduction of $\mathrm{CO}$ due to combination of booster additive and more oxygen present during combustion, thus the combustion will become more complete. However, NOx emissions are higher for higher blends of CPO and higher of the engine speed.

\section{Acknowledgements}

The authors also would like to thank the Ministry of Higher Education, Malaysia for supporting this research under COE-MTUN Grant Scheme VOT.C009 and Exploratory Research Grant Scheme (ERGS) Vot. E032.

\section{References}

[1] Kalam, M. A., Majuki, H. H., Husnawan, M., Yamane, K. (2005), performance improvement of a diesel engine using additive in palm oil methyl. JSAE, 1-4

[2] Amir Khalid, Keisuke Hayashi, Yoshiyuki Kidoguchi , Tomoaki Yatsufusa, "Effect of air entrainment and oxygen concentration on endothermic and heat recovery process of diesel ignition", (2011) SAE Technical Papers, DOI: 10.4271/2011-01-1834.

[3] Amir Khalid, "Effect of Ambient Temperature and Oxygen Concentration on Ignition and Combustion Process of Diesel Spray". Asian Journal of Scientific Research, 2013. pp.1-11.

[4] Balat, M., Balat, H. (2008). A critical review of biodiesel as a vehicular fuel. Energy Conversion and Management. 49. 2727-2741.

[5] Adaileh, W. M., \& AlQdah, K. S. (2012). Performance of Diesel Engine Fuelled by a Biodiesel Extracted From A Waste Cocking Oil. Energy Procedia, 18, 1317-1334. doi:10.1016/j.egypro.2012.05.149.

[6] Amir Khalid, N.Tamaldin, M. Jaat, M. F. M. Ali, B. Manshoor, Izzuddin Zaman, "Impacts of biodiesel storage duration on fuel properties and emissions", Procedia Engineering, volume 68, 2013, Pages 225 - 230, Elsevier, 2013, DOI: 10.1016/j.proeng.2013.12.172.

[7] Jinlin Xue, T.E.G.A.C.H., (2010). Effect of biodiesel on engine performances and emissions. Renewable and Sustainable Energy Reviews, pp. 1098-1116.

[8] Canakci, M., (2007). Combustion characteristics of a turbocharged DI compression ignition engine fueled with petroleum diesel fuels and biodiesel. Bioresource Technology, pp. 11671175.

[9] Amir Khalid, M.D. Anuar, Yusri Ishak, B. Manshoor, Azwan Sapit, Mutalib Leman, Izzuddin Zaman, "Emissions characteristics of small diesel engine fuelled by waste cooking oil", MATEC Web of Conferences, Volume 13, 2014, Article number 06006, DOI: $10.1051 /$ matecconf $/ 20141306006$

[10] Ikegami, M., Nakatani, K., Tanaka, S. and Yamane, K., "Fuel Injection Rate Shaping and Its Effects on Exhaust Emissions in a Direct-Injection Diesel Engine Using a Spool Acceleration Type Injection System ", SAE Paper 970347, 1997.

[11] Ramirez-Verduzco, L. F., B.E.G.-F., Rodriguez J. E., Alicia del Rayo Jaramillo-Jacob, (2011). Prediction of density and viscosity in biodiesel blends at various temperatures. Fuel. 91. 1751-1761.

[12] Amir Khalid, Norazwan Azman, Hanis Zakaria, B. Manshoor, Izzuddin Zaman, Azwan Sapit, Mutalib Leman, "Effects of storage duration on biodiesel properties derived from waste cooking oil", Applied Mechanics and Materials, Volume 554, 2014, Pages 494-499, DOI: 10.4028/www.scientific.net/AMM.554.494.

[13] Mustafa Canakci, A.E., Erol Arcaklioglu (2005). Performance and exhaust emissions of a biodiesel engine. Applied Energy, pp. 594-605. 